\title{
Intravenous glucagon like peptide-1 infusion does not affect dry matter intake or hypothalamic mRNA expression of neuropeptide $Y$, agouti related peptide and proopiomelanocortin in wethers
}

Article

Accepted Version

Relling, A. E., Loerch, S. C. and Reynolds, C. K. (2014) Intravenous glucagon like peptide- 1 infusion does not affect dry matter intake or hypothalamic mRNA expression of neuropeptide $\mathrm{Y}$, agouti related peptide and proopiomelanocortin in wethers. Canadian Journal of Animal Science, 94 (2). pp. 357-362. ISSN 1918-1825 doi: https://doi.org/10.4141/cjas2013-121 Available at https://centaur.reading.ac.uk/87104/

It is advisable to refer to the publisher's version if you intend to cite from the work. See Guidance on citing.

To link to this article DOI: http://dx.doi.org/10.4141/cjas2013-121

Publisher: Agricultural Institute of Canada

All outputs in CentAUR are protected by Intellectual Property Rights law, including copyright law. Copyright and IPR is retained by the creators or other copyright holders. Terms and conditions for use of this material are defined in 
the End User Agreement.

www.reading.ac.uk/centaur

\section{CentAUR}

Central Archive at the University of Reading

Reading's research outputs online 
Intravenous Glucagon Like Peptide-1 Infusion Does Not Affect Dry Matter Intake or

2 Hypothalamic mRNA Expression of Neuropeptide Y, Agouti Related Peptide and

3 Proopiomelanocortin in Wethers.

$4 \quad$ Alejandro E. Relling ${ }^{1,2, \dagger}$, Steven C. Loerch $^{2}$, Christopher K. Reynolds ${ }^{3}$

$5 \quad{ }^{1}$ Ohio State University Interdisciplinary Nutrition Program (OSUN), and

$6{ }^{2}$ Department of Animal Sciences, The Ohio State University, OARDC, 1680 Madison Ave.,

7 Wooster 44691-4096

$8{ }^{3}$ School of Agriculture, Policy and Development, University of Reading, Earley Gate, Reading

9 RG6 6AR, United Kingdom.

10 Correspondence: Alejandro Relling, arelling@fcv.unlp.edu.ar

$11 \dagger$ Current address: IGEVET, CCT-La Plata, CONICET; Laboratorio de Nutrición Animal,

12 Facultad de Ciencias Veterinarias. Universidad Nacional de La Plata. Calle 60 y 118, CP

13 B1900AVW. La Plata, Buenos Aires, Argentina.

\section{ABSTRACT}

The objectives of the present study were to determine effects of jugular vein infusions of

17 glucagon like peptide-1 (GLP-1) and dietary fat inclusion on dry matter intake, nutrient 18 digestibility and hypothalamic mRNA concentration of neuropeptide Y, agouti related peptide, 19 and proopiomelanocortin in growing sheep. Thirty six wethers were used $(40.7 \pm 3.3 \mathrm{~kg} \mathrm{BW})$. 20 Treatments were a control diet $(n=11)$, dietary addition $(6 \%$ of dry matter $)$ of Ca salts of palm 21 oil fatty acids $(\mathrm{n}=12)$, or 6-d jugular vein infusions of $0.155 \mu \mathrm{g} / \mathrm{kg}$ body weight/day of GLP-1

$22(\mathrm{n}=11)$. Hormone concentrations were measured in jugular vein plasma from samples taken on 23 day 1, 4 and 6. On d 7, the wethers were slaughtered for hypothalamus collection to measure 
24 mRNA concentration. The dietary addition of $6 \%$ of Ca salts of palm oil increased plasma GLP-

251 concentration $(P<0.01)$ and decreased dry matter intake on day 1 , but not on day 6 (time $\mathrm{x}$

26 treatment interaction, $P<0.05)$. The infusion of GLP-1 did not change dry matter intake $(P>$

27 0.20), but increased neutral detergent fibre digestibility $(P<0.01)$. In conclusion, glucagon like

28 peptide-1 infusion or feeding fat did not decrease dry matter intake or affect hypothalamic 29 neuropeptide mRNA concentrations of sheep.

\section{RÉSUMÉ}

Les objectifs de cette étude étaient d'évaluer l'effet des infusions dans la veine jugulaire

32 du glucagon-like peptide-1 (GLP-1) et de l'addition alimentaire de matières grasses sur

33 l'ingestion de matière sèche (IMS), la digestibilité des nutriments et la concentration de l'ARNm

34 dans l'hypothalamus du neuropeptide Y (NPY), de la protéine agoutie (AgRP), et de la pro-

35 opiomélanocortine $(\mathrm{POMC})$. Trente-six béliers ont été utilisés $(40.7 \pm 3.3 \mathrm{~kg})$. Les traitements

36 ont été un régime témoin (n 11), addition alimentaire (6\% de la MS) de sels de Ca d'acides

37 palmitiques (n12), ou 6 jours (j) d'infusion dans la veine jugulaire de $0.155 \mu \mathrm{g} / \mathrm{kg}$ PC/j de GLP-1

38 (n 11). Les concentrations d'hormones ont été mesurées dans le plasma de la veine jugulaire des

39 échantillons prélevés le jour 1,4 et 6 . Le jour 7, les béliers ont été abattus pour la collecte de

40 l'hypothalamus pour mesurer la concentration de l'ARNm de NPY, AgRP et POMC. L'ajout de

$416 \%$ de sels de Ca d'acides palmitiques a augmenté la concentration plasmatique de GLP-1 (P

$42<0,01$ ) et diminué l'lMS du j 1, mais pas du j 6 (interaction de temps $\mathrm{x}$ traitement, $\mathrm{P}<0,05$ ).

43 L'infusion de GLP-1 n'a pas changé l'IMS ( $\mathrm{P}>0,20)$, mais a augmenté la digestibilité des fibres

44 au détergent neutre $(\mathrm{P}<0,01)$. Il n'y avait aucune différence dans la concentration de l'ARNm de

45 NPY, AgRP ou POMC en raison de l'infusion de GLP-1 ou de l'addition alimentaire de matières 
grasses. En conclusion, la seule perfusion intraveineuse de GLP-1 n'a pas diminué l'IMS chez les

47 ovins en croissance.

48 Mots-clés: glucagon-like peptide-1, ingestion de matière sèche, mouton, neuropeptides

49 hypothalamiques

51 Running head: Relling et al. Glucagon like peptide 1 infusion in sheep

52 Keywords: glucagon-like peptide-1, dry matter intake, sheep, hypothalamic neuropeptide mRNA

54 Abreviations: AgRP, agouti-related peptide; CP, crude protein; DM, dry matter; DMI, dry 55 matter intake; FA, fatty acids; GLP-1, glucagon-like peptide-1(7, 36) amide; ICV, 56 intracerebroventricular; NDF, neutral detergent fibre; NPY, neuropeptide Y; OM, organic 57 matter; POMC, proopiomelanocortin.

In nonruminants, increasing plasma glucagon-like peptide-1(7, 36) amide (GLP-1) concentration decreases feed intake (Turton et al., 1996). In ruminants, an increase in plasma

62 GLP-1 concentration has been associated with a decrease in dry matter intake (DMI) when fat 63 was added to the diet (Relling and Reynolds, 2007; Bradford et al., 2008, Relling et al., 2010). 64 Also, intrajugular infusion of GLP-1 in wethers decreased DMI to a similar extent as feeding fat 65 (Relling et al., 2011). However, the central mechanism of how GLP-1 regulates feed intake is not 66 certain. In fasted rats, intracerebroventricular (ICV) infusion of GLP-1 did not change mRNA 67 concentration for neuropeptide Y (NPY) (Turton et al., 1996). In contrast, Seo et al. (2008) 
reported that ICV infusion of GLP-1 decreased NPY and agouti-related peptide (AgRP) and increased proopiomelanocortin (POMC) mRNA concentration in the hypothalamus of fasted rats. In ruminants, in vitro culture of sheep hypothalamus in media containing GLP-1 did not

71 change the relative concentration of NPY, AgRP or POMC mRNA (Relling et al., 2012).

72 However, an increase in NPY and AgRP mRNA was associated with an increase in plasma GLP731 concentration and a decrease in DMI when fat was fed to growing lambs (Relling et al., 2010).

74 There is a paucity of information on the effect of intravenous infusion of GLP-1 on the mRNA 75 concentration for hypothalamic neuropeptides associated with DMI regulation and its association 76 with DMI. Based on the cited literature, we hypothesized that increases in plasma GLP-1 77 concentration within physiological concentrations, due to continuous jugular vein infusion of 78 GLP-1 or by feeding fat, would decrease DMI. We also hypothesized that decreases in DMI 79 would be associated with changes in hypothalamic gene expression of NPY, AgRP and POMC. 80 Therefore the objective of our study was to determine the effect of a continuous jugular vein 81 infusion of GLP-1 or feeding fat on plasma GLP-1 concentration, DMI, and mRNA 82 concentration of the neuropeptides NPY, AgRP and POMC in growing wethers.

\section{MATERIALS AND METHODS}

Animal care followed guidelines recommended in the Guide for the Care and Use of Agricultural Animals in Agricultural Research and Teaching (FASS, 1998) and procedures used

87 were approved by the Animal Care Committee of the Ohio Agricultural Research and 88 Development Center.

Three weeks before the start of the experiment, 36 Targhee x Hampshire wethers $(40.7 \pm$ $90 \quad 3.3 \mathrm{~kg} \mathrm{BW}$ ) were fed a pelleted control diet (Table 1) formulated to meet nutrient requirements 
91 of growing lambs according to the National Research Council (NRC, 1985). The wethers were 92 grouped by weight and housed in three pens with 12 wethers each. Daily rations were provided at $0800 \mathrm{~h}$, and wethers were fed for ad libitum intake of dry matter (DM, 10\% refusal) throughout the study. Treatments were $7 \mathrm{~d}$ of: 1) control diet (CONT); 2) supplemental dietary fat (Ca-salts of palm oil) at $6 \%$ of ration DM (FAT); 3) control diet with intravenous GLP-1 (GLP-1; $0.155 \mu \mathrm{g} / \mathrm{kg} \mathrm{BW/d} \mathrm{of} \mathrm{GLP-1(7-36)} \mathrm{amide} \mathrm{H6795,} \mathrm{Bachem} \mathrm{California} \mathrm{Inc,} \mathrm{CA)} \mathrm{in} 1 \mathrm{~L}$ of saline $(0.9 \% \mathrm{NaCl})$. These treatments were selected based on previous results in growing lambs (Relling et al., 2011), where the infusion of $0.155 \mu \mathrm{g} / \mathrm{kg} \mathrm{BW} / \mathrm{d}$ of GLP-1(7-36) amide produced a similar increase in plasma GLP-1 concentration as adding 6\% supplemental fat to the diet. The wethers on the CONT and FAT treatments received a control intravenous infusion of $1 \mathrm{~L}$ of sterile saline solution daily. The hormone solutions and the saline solutions were made and infused as described in Relling et al. (2011). established as described previously (Relling et al., 2011). Two animals experienced a drop in DMI to less than $50 \%$ of the previous day's intake when lambs were moved into the metabolic crates. Therefore, before the infusions started, one wether on the control treatment and one wether on the GLP-1 treatment 
et al., 2011) and started at $1000 \mathrm{~h}$ on day 1 of the experimental period. Briefly, GLP-1 solutions were prepared using $1 \mathrm{~L}$ of sterile saline solution (9 $\mathrm{g} / \mathrm{L}$ of $\mathrm{NaCl}$; VWR International, West Chester, PA). The liter of saline solution was infused at a rate of $0.725 \mathrm{ml} / \mathrm{min}$ during $23 \mathrm{~h}$. The wethers fed the control and the fat supplemented diets were intravenously infused with $1 \mathrm{~L}$ of sterile saline solution $(9 \mathrm{~g} / \mathrm{L}$ of $\mathrm{NaCl}$ ). The targeted dose of GLP-1 infused was calculated using a single compartment, first-order kinetic hormone degradation model, based on the equation:

Increase in hormone concentration x 0.693/half life.

The half life used for this equation was 5 min for GLP-1 (Perfetti and Merkel, 2000). The value, 0.693, is the slope of the first order degradation. The target increase for GLP-1 was based on a previous report (Relling et al., 2011).

The bottles with sterile saline solution and those with GLP-1 in solution were kept on ice during the infusion. The infusion line from the bottle to the animal was sterilized using an ethylene oxide (EtO) gas (Cole-Parmer, Vernon Hills, IL). The connection between the bottle with the infusion and the infusion line included a sterile $0.45 \mu \mathrm{m}$ syringe filter (Whatman International Ltd, Florham Park, NJ).

Between the end of each day's infusion and the start of the following day, the infusion lines were flushed with sterile saline solution $(9 \mathrm{~g} / \mathrm{L}$ of $\mathrm{NaCl})$ and the filters were changed. Feed was offered daily at $1300 \mathrm{~h}$ and the refusals were removed and weighed $23 \mathrm{~h}$ later at $1200 \mathrm{~h}$. For digestibility and plasma samples, samples were collected and processed as described previously (Relling et al., 2011). Briefly, to measure digestibility, total fecal collection was performed daily during the last $5 \mathrm{~d}$ of each experimental period. Five percent of the total daily feces was collected and composited for analysis of $\mathrm{DM}\left(100^{\circ} \mathrm{C}\right.$ oven for $\left.24 \mathrm{~h}\right)$, neutral detergent fibre (NDF, (Ankom $^{200}$ Fiber Analyzer, ANKOM Technology, Fairport, NY), crude protein (CP, Kjeldahl N 
139 x 6.25), fatty acids (FA, Sukhija and Palmquist, 1988), and ash (AOAC 1990) concentration.

140 Blood samples $(10 \mathrm{ml})$ were taken 6 and $8 \mathrm{~h}$ after feed was offered on day 1, 4, and 6 of each

141 experimental period. Blood samples were immediately transferred into polypropylene tubes

142 containing solutions of disodium EDTA and benzamidine $\mathrm{HCl}(1.6 \mathrm{mg}$ and $4.7 \mathrm{mg} / \mathrm{ml} \mathrm{blood}$,

143 respectively) and placed on ice. After centrifugation for $25 \mathrm{~min}$ at $1800 \mathrm{x} g$ and $4^{\circ} \mathrm{C}$, plasma was

144 partitioned into individual polypropylene tubes for each analysis to be performed, flash frozen

145 using liquid $\mathrm{N}_{2}$ within 40 min of sample collection, and stored at $-80^{\circ} \mathrm{C}$ until analyzed. Samples

146 from the infusate were taken after the in line filters during the first sampling time on day 4 to

147 confirm that the infusate contained the correct concentration of GLP-1. Measured GLP-1

148 concentrations in the infusate were within $98.2 \%( \pm 3.7, \mathrm{P}=0.798)$ of targeted concentrations.

149 Concentrations of insulin and GLP-1 were measured using radioimmunoassays as described

150 previously (Reynolds et al., 1989; Benson and Reynolds, 2001). The intra-assay CV averaged

151 less than $12.5 \%$ for insulin and less than $11 \%$ for GLP-1. Minimum sensitivities (90\% of zero

152 standard binding) of the insulin and GLP-1 assays were 0.0027 and $0.001 \mathrm{ng} /$ tube, respectively.

153 Plasma glucose concentration was measured using a colorimetric assay (\#1070 Glucose Trinder,

154 Stanbio Laboratory, Boerne, TX). Plasma NEFA concentration was measured using microtiter

155 plates and a plate reader in a two-reaction, enzyme based assay (Wako Chemicals USA,

156 Richmond, VA) as described by Johnson and Peters (1993).

157 The morning of the seventh day of infusions, the lambs were transported $165 \mathrm{~km}$

158 (transport time was $100 \mathrm{~min}$ ) to an abattoir for hypothalamus collection. It has been previously 159 reported (Relling et al., 2010) that there were no effects of the same transportation routine on the 160 mRNA concentration for the same genes in the hypothalamus of similar lambs (Relling et al., 161 2010). The hypothalamus was collected within 1 hour after arrival to the slaughter house as 
162 described by Relling et al. (2010). During hypothalamus collection, one sample from a lamb on

163 the GLP-1 treatment was lost due to damage of the brain caused by the captive bolt used at 164 slaughter.

165 To measure hypothalamic mRNA concentration for NPY, AgRP and POMC, the protocol 166 and primers used were as described by Relling et al. (2010). Briefly, RNA was extracted with 167 TRIzol® (Invitrogen Carlsbad, CA) using procedures recommended by the manufacturer. 168 Concentration of RNA was determined by measuring absorbance at $260 \mathrm{~nm}$. Reverse 169 transcription (RT) PCR was performed as described by Ndiaye et al. (2008). The relative mRNA 170 concentration of NPY, AgRP, and POMC were determined by quantitative RT PCR using the 171 DNA Engine Monitor 2 (BioRad Laboratories, Hercules, CA). Primers for NPY, AgRP and 172 POMC were validated in sheep hypothalamic tissue by cDNA purification and sequencing. 173 Oligonucleotide primers for NPY, AgRP and POMC were obtained from Qiagen Operon 174 Biotechnologies (Alameda, CA). The primer sequences used are described on Table 2. The 175 quantitative RT PCR was run for a maximum of 35 cycles, under the following conditions: 176 denaturing at $94^{\circ} \mathrm{C}$ for $30 \mathrm{~s}$, annealing at $60^{\circ} \mathrm{C}$ for $60 \mathrm{~s}$, and extension at $72^{\circ} \mathrm{C}$ for $60 \mathrm{~s}$. 177 Concentrations of NPY, AgRP and POMC were normalized to cyclophilin B mRNA expression 178 in the same sample to determine the relative mRNA concentrations of NPY, AgRP, and POMC. 179 Homologous standard curves were prepared from purified NPY, AgRP, and POMC cDNA PCR 180 products to calculate the steady-state concentration of NPY, AgRP, and POMC mRNA in 181 triplicate wells for each sample. The PCR amplification products were electrophoretically 182 separated on $1.5 \%$ agarose gels and visualized with ethidium bromide. For initial validation, the 183 specific band corresponding to the size of the expected NPY, AgRP, and POMC cDNA fragment 
184 was cut and purified using the QIAquick Gel Extraction Kit (Qiagen Sciences) for sequence confirmation.

The data were statistically analyzed as a complete randomized block design with repeated measurements in time using the MIXED procedure of SAS (Version 9.1, SAS Institute, Cary, NC) and a model testing the random effects of wether and block, and the fixed effect of treatment and time and their interaction. The two daily plasma samples for hormones and metabolites from the three days of sampling in each experimental period were analyzed in the lab individually but the average for each day was used in the statistical analysis. For digestibility and mRNA concentration data, a similar statistical model was used without the effect of time and its interaction. When the time by treatment interaction was significant, the slice option of SAS was used for separation of means. Fisher's protected LSD test was used for means separation at a $P$ value of 0.05 , for digestibility, mRNA concentration, and when the time by treatment interaction was not significant $(P>0.10)$. Trends were discussed for $P$ values between 0.05 and 0.10 .

\section{RESULTS}

There was a time by treatment interaction for DMI $(P<0.05$; Figure 1$)$, due to a greater DMI for GLP-1 and control-fed wethers compared with the fat-fed wethers on day 1, but no difference in DMI on day 6 for the three treatments. Metabolizable energy intake and digestibility of DM, CP, FA and organic matter $(\mathrm{OM})$ was not different among the treatments $(P$ $>0.10$; Table 3$)$. The addition of dietary fat decreased $(P<0.05)$ and there was a trend for GLP1 infusion to increase $(P<0.10)$ NDF digestibility compared with control fed wethers. Feeding fat or GLP-1 infusion did not change plasma concentrations of insulin and glucose $(P>0.30$; Table 4) compared with the control wethers. Compared with control wethers, plasma GLP-1 
207 (Figure 2) and NEFA concentrations (Table 4) increased due to additional dietary fat $(P<0.05)$,

208 but were not affected $(P>0.10)$ by GLP-1 infusion. Hypothalamic mRNA concentrations of 209 NPY, AgRP and POMC were not affected by treatments $(P>0.25$; Table 5).

\section{DISCUSSION}

The objective of the experiment was to infuse GLP-1 to achieve a similar plasma

212 concentration as had been previously observed in response to feeding supplemental fat (Relling

213 et al., 2011). We hypothesized that continuous jugular vein infusion of GLP-1 (within

214 physiological concentrations) or feeding fat would decrease DMI. A second objective was to

215 elucidate if the decrease in DMI typically observed when feeding fat was associated with

216 changes in mRNA concentration of the neuropeptides NPY, AgRP and POMC in response to

217 GLP-1 or by other non GLP-1 effects of feeding fat.

In the present study there was an interaction of treatments and days on DMI. Similar

219 amounts of fat or GLP-1 infusion tended to decrease DMI in sheep in previous studies compared

220 with control animals (Reynolds et al., 2006; Relling et al., 2010; Relling et al., 2011). In the

221 present study, wethers fed fat had a smaller DMI on day 1 compared with control wethers.

222 However, fat-fed wethers had an increase in DMI over time, such that by day 6 they had the

223 same DMI as control wethers. Also, wethers infused with GLP-1 started on day 1 with a greater

224 DMI compared with control wethers, and then their DMI tended to decrease toward day 3. As

225 observed in the present study, Relling et al. (2011) reported that dietary inclusion of $6 \%$ fat

226 tended to decrease NDF digestibility in sheep. Harvatine and Allen (2006) reported that the

227 inclusion of fat in dairy cow diets decreased ruminal digestibility, but not total tract digestibility

228 of NDF. A possible reason for the decrease in NDF digestibility in wethers fed diets containing

229 increased fat in the present experiment could be because of increased rate of passage, as 
230 observed in sheep fed a similar fat supplemented diet (Relling et al., 2011); however, rate of 231 passage was not measured in the current experiment. The infusion of GLP-1 tended to increase 232 NDF digestibility compared with control-fed wethers. Our assumption was that an increase in 233 NDF digestibility with GLP-1 infusion would be due to a decrease in gut motility and increased 234 retention time of fibre in the rumen and/or hindgut, allowing more time for NDF fermentation by 235 gut microbes. Results of the present study may be because of an increase in digesta retention 236 time, but in a previous study (Relling et al., 2011) GLP-1 infusion at the same rate had no effect 237 on rate of passage or NDF digestibility. In addition, the effect of fat on NDF digestibility 238 observed in the present study was opposite to the effect of GLP-1 infusion, but feeding fat 239 increased plasma concentration of GLP-1. These observations suggest that the effects of fat on 240 NDF digestibility were not due to an increase in GLP-1 concentration for the fat treatment.

241 Feeding fat increased plasma GLP-1 concentration, but the infusion of GLP-1 did not 242 change plasma GLP-1 concentration compared with control-fed wethers. As shown in Figure 2, 243 infusion of GLP-1 tended to increase plasma GLP-1 concentration on day 4 but then 244 concentrations decreased on day 6. The lack of response of plasma GLP-1 concentration to GLP2451 infusion could be due to a decrease in endogenous secretion into blood, an increased clearance 246 rate, or both; however, we are not aware of studies that can support this assumption. This lack of 247 response of plasma GLP-1 concentration was unexpected and may in part explain the lack of 248 effects of GLP-1 infusion on DMI. However, this lack of response in the GLP-1 infused wethers 249 does not explain the observed increase in NDF digestibility.

As has been observed previously, feeding supplemental fat increased plasma NEFA 251 concentration (Gagliostro and Chilliard, 1991; Relling and Reynolds, 2007), perhaps due to a 252 higher plasma concentration of lipoproteins (Gagliostro and Chilliard, 1991). This increase in 
plasma NEFA occurred concurrently with an increase in plasma GLP-1 concentration. However,

254 infusion of GLP-1 did not increase plasma NEFA concentration. The lack of response on plasma

255 NEFA concentration observed in the present study and observed previously (Relling et al., 256 2011), suggests GLP-1 infusion does not change plasma NEFA concentration.

In the present study, there were no differences in hypothalamic mRNA concentrations for

258 the neuropeptides NPY, AgRP and POMC due to feeding fat or GLP-1 infusion. It has been 259 observed that feeding the same amount of supplemental fat deceases DMI and increases NPY 260 and AgRP (Relling et al., 2011) in growing wethers. The reason for the lack of response of 261 mRNA concentrations for hypothalamic neuropeptides to supplemental fat in the present 262 experiment is not certain. In the case of the GLP-1 infusion treatment, it may have been due to 263 the inability to achieve a sustained increase in plasma concentrations with the dose infused.

264 However, the lack of response on hypothalamic neuropeptide mRNA concentration is also 265 reflected by the lack of differences on DMI observed on day 6. Despite this lack of response of 266 mRNA concentration, the actual neuropeptide concentration or secretion was not measured. It 267 has been observed that changes in the mRNA concentration are associated with changes in the 268 peptide concentration (Kameda et al., 2001); however, we are not aware of any study which has 269 measured the association between mRNA concentration of the neuropeptide and the secretion of 270 its gene product. In conclusion, glucagon like peptide-1 infusion or feeding fat did not decrease 271 dry matter intake or affect hypothalamic neuropeptide mRNA concentrations of sheep.

\section{ACKNOWLEDGMENTS}

We are grateful to Dr. H. Zerby, D. O’Diam and the staff of the OSU Meats Laboratory 275 for their assistance with tissue collection, to Drs. J. L. Pate and K. Ndiaye for their help in the 
276 validation of the PCR work, and to P. Tirabasso, G. Lowes and D. Clevenger for technical

277 assistance. Salaries were provided by state and federal funds appropriated to the Ohio 278 Agricultural Research and Development Center, The Ohio State University.

279

280

281

282

283

284

285

286

287

288

289

290

291

292

293

294

295

296

297

\section{REFERENCES}

Association of Official Analytical Chemists. 1990. Official Methodsof Analysis. Vol. 1 15th ed. AOAC, Arlington, VA.

Benson, J. A.; Reynolds, C. K. 2001. Effects of abomasal infusion of long-chain fatty acids on splanchnic metabolism of pancreatic and gut hormones in lactating dairy cows. J. Dairy Sci. 84: $1488-1500$.

Bradford, B. J.; Harvatine, K. J.; Allen, M. S. 2008. Dietary unsaturated fatty acids increase plasma glucagon-like peptide-1 and cholecystokinin and may decrease premeal ghrelin in lactating dairy cows. J. Dairy Sci. 91: 1443-1450.

FASS, 1998. Guide for the Care and Use of Agricultural Animals in Agricultural Research and Teaching. Consortium for Developing a Guide for the Care and Use of Agricultural Animals in Agricultural Research and Teaching. Savoy, IL.

Gagliostro, G.; Chilliard, Y. 1991. Duodenal rapeseed oil infusion in early and midlactation cows. 4. In vivo and in vitro adipose tissue lipolytic responses. J. Dairy Sci. 74: 1830-1843.

Harvatine, K. J.; Allen, M. S. 2006. Effects of Fatty Acid Supplements on Ruminal and Total Tract Nutrient Digestion in Lactating Dairy Cows. J. Dairy Sci. 89: 1092-1103.

Johnson, M. M.; Peters, J. P., 1993. Technical note: An improved method to quantify nonesterified fatty acids in bovine plasma. J. Anim. Sci.71: 753-756. 
Kameda. Y.; Miura, M.: Nishimaki, T. 2001. Localization of neuropeptide Y mRNA and peptide in the chicken hypothalamus and their alterations after food deprivation, dehydration, and castration. J Comp Neurol. 436:376-388.

Murphy, T. A.; Loerch, S. C.; Smith, F. E., 1994. Effects of feeding high-concentrate diets at restricted intakes on digestibility and nitrogen metabolism in growing lambs. J. Anim. Sci. 72: 1583- 1590.

Ndiaye, K.; Poole, D. H.; Pate, L. J., 2008. Expression and regulation of functional oxytocin receptors in bovine T lymphocytes. Biol. Reprod. 78: 786-793.

NRC. 1985. Nutrient Requirements of Sheep, Sixth Revised Edition. National Academy of Sciences, Washington, DC.

Perfetti, R.; Merkel, P. 2000. Glucagon-like peptide-1: A major regulator of pancreatic beta cell function. Eur. J. Endocrinol. 143:717-725.

Relling, A. E.; Reynolds, C. K. 2007. Feeding rumen-inert fats differing in their degree of saturation decreases intake and increases plasma concentrations of gut peptides in lactating dairy cows. J. Dairy Sci. 90: 1506-1515.

Relling, A. E.; Pate, J. L.; Reynolds, C. K.; Loerch, S. C. 2010. Effect of restriction feeding and supplementary dietary fat on gut peptides and hypothalamic neuropeptides concentration in growing wethers. J. Anim. Sci. 88:737-748.

Relling, A. E.; Reynolds, C. K.; Loerch, S. C. 2011. Effect of feeding fat or intrajugular infusion of glucagon-like peptide-1 and cholecystokinin on dry matter intake, digestibility, and digesta rate of passage in growing wethers. J. Anim. Sci. 89:168-178. 
Relling, A, E.; Lee, K.; Loerch, S. C.; Reynolds, C. K. 2012. Effects of glucose, propionate and splanchnic hormones on neuropeptide mRNA concentrations in the ovine hypothalamus. J. Anim. Physiol. Anim. Nutr. 96: 648-54.

Reynolds, C. K.; Cannon, V.; Loerch, S. C. 2006. Effects of forage source and supplementation with soybean meal and marine algal oil on milk fatty acid composition of ewes. Anim. Feed Sci. Technol. 131: 333-357.

Reynolds, C. K.; Huntington, G. B.; Elsasser, T. H.; Tyrrell, H. F.; Reynolds, P. J. 1989. Net metabolism of hormones by portal drained viscera and liver of lactating Holstein cows. J. Dairy Sci. 72: 1459-1468.

Seo, S.; Ju, S.; Chung, H.; Lee, D.; Park, S. 2008. Acute effects of glucagon-like peptide-1 on hypothalamic neuropeptide and AMP activated kinase expression in fasted rats. Endocr. J. 55: $867-874$

Sukhija, P. S.; Palmquist, D. L. 1988. Rapid method for determination of total fatty acid content and composition of feedstuffs and feces. J. Agric. Food Chem. 36:1202-1206.

Turton, M. D.; O'Shea, D.; Gunn, I.; Beak, S. A.; Edwards, C. M.; Meeran, K.; Choi, S. J.; Taylor, G. M.; Heath, M. M.; Lambert, P. D.; Wilding, J. P.; Smith, D. M.; Ghatei, M. A.; Herbert, J.; Bloom, S. R. 1996. A role for glucagon-like peptide-1 in the central regulation of feeding. Nature 379: 69-72. 
338 Table 1

339 Formulation and chemical composition of the control diet and fat supplemented diets

Diet $(\%$ of DM)

\section{Control and}

\begin{tabular}{|c|c|c|}
\hline Item & GLP-1 $1^{\mathrm{z}}$ & Fat \\
\hline \multicolumn{3}{|l|}{ Ingredients } \\
\hline Alfalfa meal, $17 \% \mathrm{CP}$ & 20.00 & 20.00 \\
\hline Soy hulls & 20.00 & 20.00 \\
\hline Ground corn & 48.59 & 43.90 \\
\hline Ca salts of palm oil ${ }^{\mathrm{y}}$ & - & 6.00 \\
\hline Soybean meal, $48 \% \mathrm{CP}$ & 8.00 & 8.09 \\
\hline Urea & 0.50 & 0.60 \\
\hline Limestone & 1.50 & - \\
\hline Monosodium phosphate & 0.05 & 0.05 \\
\hline Trace mineral salts & 0.50 & 0.50 \\
\hline Vitamin A $(30,000 \mathrm{IU} / \mathrm{g})$ & 0.01 & 0.01 \\
\hline Vitamin D $(3,000 \mathrm{IU} / \mathrm{g})$ & 0.01 & 0.01 \\
\hline Vitamin E (44 IU/g) & 0.05 & 0.05 \\
\hline Selenium (200 mg/g) & 0.09 & 0.09 \\
\hline Animal-vegetable fat & 0.30 & 0.30 \\
\hline Ammonium chloride & 0.40 & 0.40 \\
\hline
\end{tabular}


Chemical composition

$\begin{array}{lcc}\text { NDF } & 28.01 & 24.68 \\ \text { CP } & 14.96 & 15.75 \\ \text { Ash } & 5.92 & 5.16\end{array}$

$\begin{array}{lll}\text { Total fatty acids } & 2.88 & 7.25\end{array}$

340

$341{ }^{\mathrm{z}}$ Intravenous GLP-1infused

$342{ }^{\mathrm{y}}$ Megalac $®$, Church and Dwight Co., Inc., Princeton, NJ. 
343 Table 2. Primer sequences used for the reverse transcriptase quantitative PCR

344

\begin{tabular}{lll}
\hline & Forward & Reverse \\
Item & Sequence, 5' to 3' & Sequence, 5' to 3' \\
\hline NPY $^{\mathrm{z}}$ & tcagcgctgcgacactacat & gcagagactggagagcaagt \\
$\mathrm{AgRP}^{\mathrm{z}}$ & cctgaggaagccttattcct & caggattcatgcagccttac \\
$\mathrm{POMC}^{\mathrm{z}}$ & agtgtcaggacctcaccacg & gctgctgctaccattccga \\
\hline $\mathrm{z}$ NPY = Neuropeptide Y; AgRP = Aguti-related peptide; POMC = Proopiomelanocortin.
\end{tabular}

346

347

348

349

350

351

352

353

354

355

356

357

358 
359 Table 3

360 Dry matter intake (DMI), metabolizable energy intake (MEI) and digestibility of diet

361 components in growing wethers fed a control diet, the control diet plus $6 \%$ Ca salts of palm oil

362 (6\% Fat), or infused intravenously with $0.155 \mu \mathrm{g} / \mathrm{kg} \mathrm{BW} /$ day of GLP-1.

363

\section{Treatments}

\begin{tabular}{lccccc} 
& Control & $6 \%$ Fat & GLP-1 & S.E. & $P$ \\
\cline { 2 - 3 } Lambs per treatment & 11 & 12 & 11 & & \\
DMI (kg/d) ${ }^{\mathrm{z}}$ & 1.33 & 1.29 & 1.35 & 0.07 & 0.83 \\
MEI (Mcal/d) & 3.44 & 3.73 & 3.58 & 0.19 & 0.68 \\
Digestibility (\%) & & & & & \\
Dry matter & 69.51 & 69.26 & 71.51 & 0.96 & 0.21 \\
Organic matter & 53.34 & 50.79 & 49.74 & 1.45 & 0.22 \\
Neutral detergent fibre & 48.38 & $40.31^{*}$ & $52.39^{\dagger}$ & 1.64 & 0.01 \\
$\quad$ & 65.44 & 67.76 & 67.30 & 1.00 & 0.24 \\
Crude protein & 82.09 & 85.70 & 80.02 & 2.00 & 0.17 \\
Fatty acids & & & & & \\
\hline
\end{tabular}

364

$365 *$ Differs from control, $P<0.05$.

$366 \dagger$ Differs from control, $P<0.10$.

$367 \quad \mathrm{Z}$ Time by treatment interaction $(P<0.05)$. 
369 Table 4

370 Plasma hormone and metabolite concentration in growing wethers fed a control diet, the control

371 diet plus $6 \%$ Ca salts of palm oil (6\% Fat), or infused intravenously with $0.155 \mu \mathrm{g} / \mathrm{kg} \mathrm{BW} / \mathrm{day}$ of

372 GLP-1. Due to lack of time by treatment interaction values represent average of day 1, 4 and 6.

373

374

\begin{tabular}{|c|c|c|c|c|c|c|c|}
\hline \multirow[b]{2}{*}{ Item } & \multicolumn{3}{|c|}{ Treatments } & \multirow[b]{2}{*}{ S.E. } & \multicolumn{3}{|c|}{$P$} \\
\hline & Control & $6 \%$ Fat & GLP-1 & & $\operatorname{Trt}^{\mathrm{Z}}$ & Time & $\mathrm{TxT}^{\mathrm{z}}$ \\
\hline Lambs per treatment & 11 & 12 & 11 & & & & \\
\hline Insulin (pM) & 312 & 270 & 270 & 23 & 0.34 & 0.84 & 0.82 \\
\hline $\mathrm{GLP}^{-1 \mathrm{z}}(\mathrm{p} M)$ & 23 & $34^{*}$ & 25 & 2 & 0.01 & 0.44 & 0.50 \\
\hline Glucose $(\mathrm{m} M)$ & 3.63 & 3.55 & 3.57 & 0.09 & 0.73 & 0.22 & 0.20 \\
\hline $\mathrm{NEFA}^{\mathrm{z}}(\mathrm{m} M)$ & 49.54 & $77.54^{*}$ & 58.58 & 8.81 & 0.08 & 0.97 & 0.46 \\
\hline
\end{tabular}

375

376

$377 \mathrm{z}$ Trt= treatment effect; TxT = time by treatment interaction effect; GLP-1= glucagon-like

378 peptide-1 (7-36) amide; NEFA= non esterified fatty acid.

379 * Differs from control, $P<0.05$.

380

381 
383 Table 5

384 Hypothalamic concentrations of mRNA in growing wethers fed a control diet, the control diet 385 plus $6 \%$ Ca salts of palm oil (6\% Fat), or infused intravenously with $0.155 \mu \mathrm{g} / \mathrm{kg} \mathrm{BW} /$ day of 386 GLP-1.

387

\begin{tabular}{lccccc}
\hline & \multicolumn{3}{c}{ Treatments } \\
\cline { 2 - 4 } Item $^{\mathrm{z}}$ & Control & $6 \%$ Fat & GLP-1 & S.E. & $P$ \\
\hline Lambs per treatment & 11 & 12 & 10 & & \\
NPY & 0.786 & 0.216 & 0.137 & 0.33 & 0.37 \\
AgRP & 0.200 & 0.031 & 0.046 & 0.09 & 0.40 \\
POMC & 0.311 & 0.168 & 0.084 & 0.09 & 0.25 \\
\hline
\end{tabular}

$390{ }^{\mathrm{z}}$ Concentrations of mRNA (relative to cyclophilin B) for neuropeptide Y (NPY), agouti related 391 peptide (AgRP), and proopiomelanocortin (POMC). 


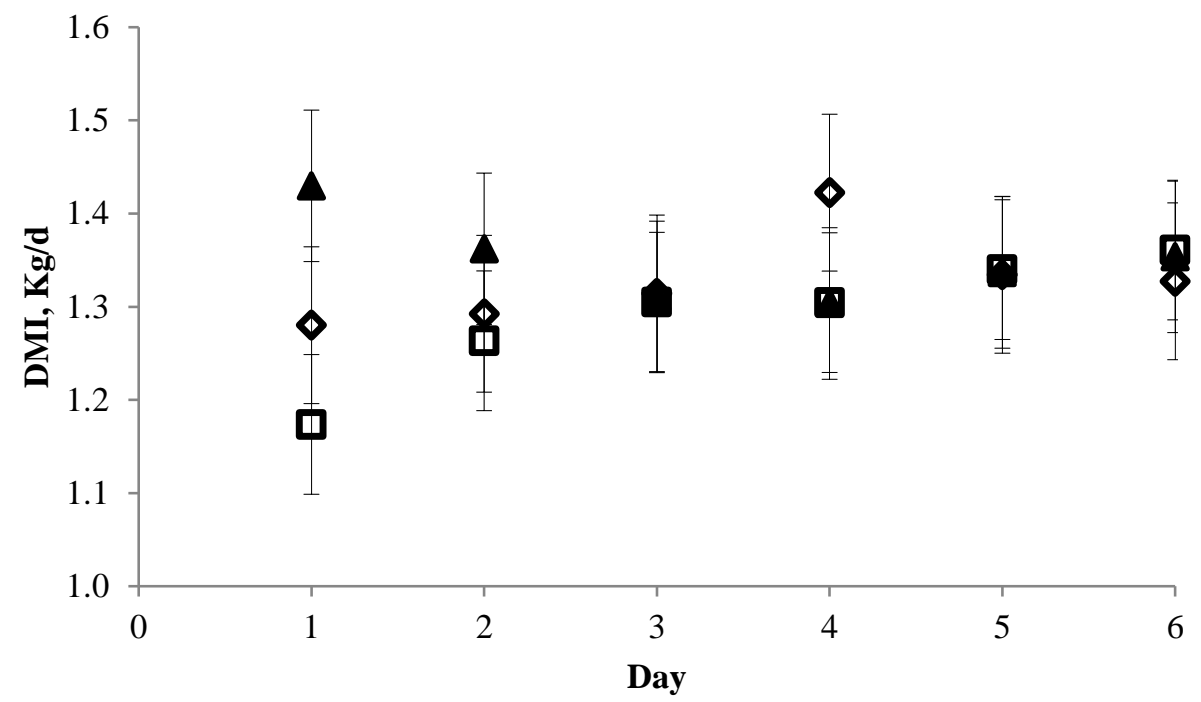

398 Figure 1

399 Dry matter intake (DMI) over 6 days in wethers fed a diet without supplemental fat $(\diamond)$ a diet 400 with the addition of $6 \%$ Ca salts of palm oil ( $\square$ ) or the control diet and infused with $0.155 \mu \mathrm{g} / \mathrm{kg}$ 401 BW/day of GLP-1 (7-36) amide $(\boldsymbol{\Delta})$. Time by treatment interaction $(P<0.05)$. 


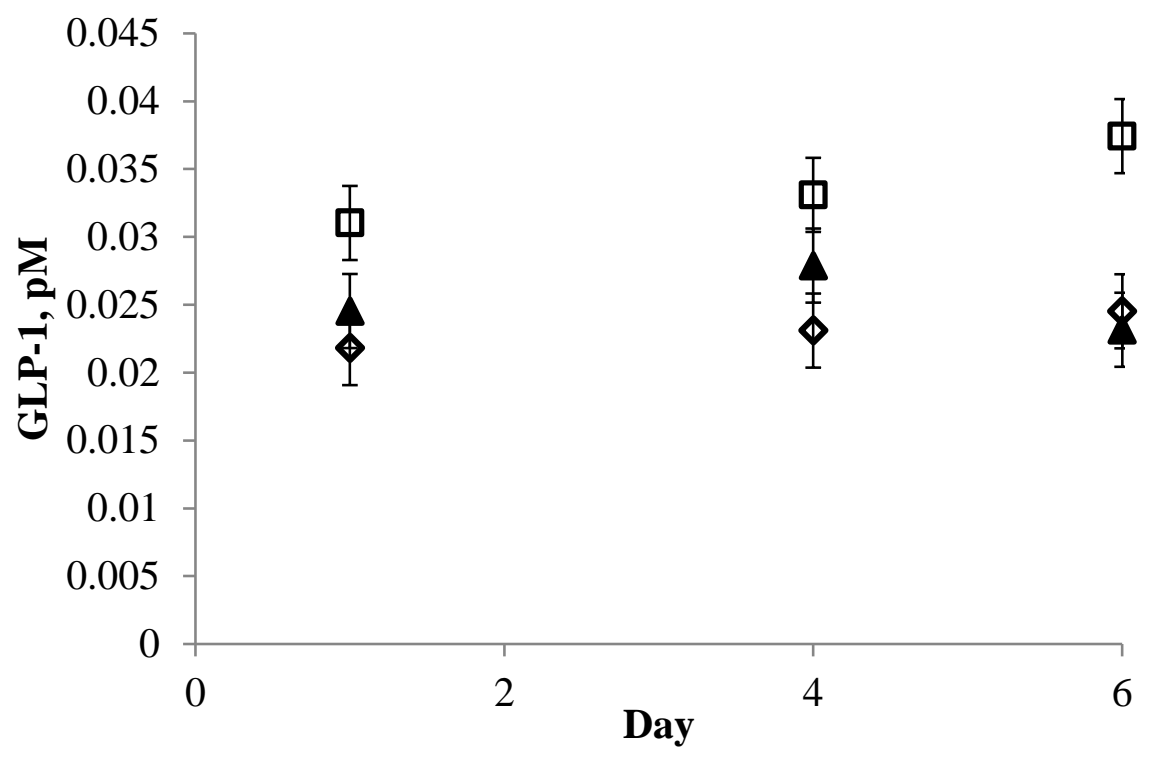

405 Figure 2

406 Plasma concentration of glucagon like peptide-1 (7-36) amide (GLP-1) over 6 days in wethers

407 fed a diet without supplemental fat $(\diamond)$ a diet with the addition of $6 \%$ Ca salts of palm oil ( $\square$ ) or 408 the control diet and infused with $0.155 \mu \mathrm{g} / \mathrm{kg} \mathrm{BW} /$ day of GLP-1 (7-36) amide ( $\mathbf{\Delta})$. Treatment 409 effect $(\mathrm{P}<0.01)$, time by treatment interaction $(P=0.50)$.

410 